\title{
The Effect of Distance Between Rows on Sowing and of Mineral Fertilisers on a Complex Forage Mixture in Condition Specific to Transylvania Plain
}

\author{
Anamaria MALINAS ${ }^{1}$, Ioan ROTAR ${ }^{1 *}$, Roxana VIDICAN ${ }^{1}$, Florin PĂCURAR ${ }^{1}$, \\ Adrian GLIGA ${ }^{\mathbf{1}}$, Agnes BALAZSI ${ }^{\mathbf{1}}$, Miklós NAGY ${ }^{1}$ \\ Faculty of Agriculture, UASMV Cluj-Napoca, Calea Mănăștur 3-5, Cluj-Napoca, Romania; \\ * corresponding author: rotarioan52@yahoo.fr \\ Bulletin USAMV series Agriculture 71(2)/2014 \\ Print ISSN 1843-5246; Electronic ISSN 1843-5386 \\ DOI 10.15835/buasvmcn-agr: 10840
}

\begin{abstract}
Lately an increasingly importance is shown to complex forage mixture. In Transylvania Plain detailed studies are still required for highlighting the most suitable forage mixture for this area. These are needed also to support farmers, especially in the actual context when both agricultural and livestock systems are crossing a transitional period, characterized by decreases in production from year to year. Our study aims to follow the behaviour of a complex forage mixture formed by Trifolium pratense (15\%), Lolium perenne (20\%), Festulolium (25\%), Festuca arundinacea (25\%) and Phleum pratense (15\%) under the influence of different technological inputs. The species were sown on two different distances between rows, namely $12.5 \mathrm{~cm}$ and $25 \mathrm{~cm}$ and it was fertilized with 4 different doses of mineral fertilizers and Ammonium nitrate (33.3\%) in 4 different doses, as follows: $\mathrm{V}_{1}$-control variant, unfertilized, $\mathrm{V}_{2}-\mathrm{N}_{50} \mathrm{P}_{60} \mathrm{~K}_{80}, \mathrm{~V}_{3}-\mathrm{N}_{75} \mathrm{P}_{60} \mathrm{~K}_{80}, \mathrm{~V}_{4}-\mathrm{N}_{100} \mathrm{P}_{60} \mathrm{~K}_{80}$. The present study comprises data registered in 2013, data related to green mass and dry matter (DM) production and floristic composition of the mixture studied. The results registered helped us to identify the most efficient technology both from ecologic and economic point of view, able to provide increased productions and high quality forage.
\end{abstract}

Keywords: mixture, production, floristic composition, fertilization.

\section{INTRODUCTION}

Feed requirements for at least $60 \%$ of cattle and $80 \%$ of sheep is provided by meadows, areas including perennial forage (grasses and legumes) which have a pronounced anti-entropic action on soil, the main source of phytomass (Teodor Marușca et al., 2010). The economic and ecologic importance of grassland is outstanding (Rotar, 2010). Compared to the technologies applied to other crops, appropriate technologies in perennial vegetation can achieve the fastest and most complex ecological balance in the food chain soil - plant - animal - man.

Temporary meadows are an important source of feed, which still require a series of steps for achieving a considerable increase in production and quality in the coming years. Polyculture, within which several species are grown together, can reduce dependence on external factors to culture, economic risks and food insecurity, while protecting the environment and
(Liebman, 1995). The achievement of high forage production from the temporary meadows depends largely on the species and varieties used, the types of mixtures and soil fertility. Choice of species according to climatic requirements plays an important role both in the vegetation productivity and the quality of feed produced. Picasso et al., 2011, following the behaviour of some forage species within a complex forage mixture has shown that complex forage mixture sustain a high productivity among time due to ecological complementarity between species. In order to obtain a certain proportion of species in mixture, which also enfaces feed quality, a special attention should be paid to seed mixture formation, which should have a suitable ratio between grasses and legumes (Staniak, 2011) and an optimal quantity of fertilisation.

Soil-climatic condition specific to Transylvania Plain drawn up a proper environment for agricul- 
ture development. In Transylvania detailed studies are still required for highlighting the most suitable forage mixture for this area. These are needed also to support farmers, especially in the actual context when both agricultural and livestock systems are crossing a transitional period, characterized by decreases in production from year to year. Taking into account the stated facts, our study aims to follow the behaviour of a complex forage mixture formed by Trifolium pratense (15\%), Lolium perenne (20\%), Festulolium (25\%), Festuca arundinacea (25\%) and Phleum pratense (15\%) under the influence of different technological inputs. Through these we aimed to identify the most efficient technology both from ecologic and economic point of view for able to provide increased productions and high quality forage.

\section{MATERIAL AND METHOD}

The experience was installed in the spring of 2012 in the field of Agricultural ResearchDevelopment Station, Turda, Romania. The soil type is phaeozem argilo iluvial vertic. The experimental sit is characterized by an annual medium temperature $(2013)$ of $10.4^{\circ} \mathrm{C}$ and annual precipitations of $523.2 \mathrm{~mm}$.

The complex forage mixture formed by Trifolium pratense $(15 \%)$, Lolium perenne $(20 \%)$, Festulolium (25\%), Festuca arundinacea (25\%) and Phleum pratense $(15 \%)$ was installed according to the subdivided parcels method: in 8 variants with 4 replications, each plot having $50 \mathrm{~m}^{2}(10 \mathrm{l}$ $\mathrm{X} 5 \mathrm{~L}$ ). The species were sown on two different distances between rows, namely $12.5 \mathrm{~cm}$ and 25 $\mathrm{cm}$. The mixture was fertilized in the beginning of
March month of every year with NPK complex and Ammonium nitrate $(33.3 \%)$ in 4 different doses: $\mathrm{V}_{1}$-control variant, unfertilized, $\mathrm{V}_{2}-\mathrm{N}_{50} \mathrm{P}_{60} \mathrm{~K}_{80}$, $\mathrm{V}_{3}-\mathrm{N}_{75} \mathrm{P}_{60} \mathrm{~K}_{80}, \mathrm{~V}_{4}-\mathrm{N}_{100} \mathrm{P}_{60} \mathrm{~K}_{80}$. The present study comprises data registered in 2013, data related to green mass and dry matter (DM) production and floristic composition of the mixture studied.

Green mass production was determined by weighting and the floristic composition after gravimetric method. The experimental plots were mowed three times/ year. Statistical interpretation of data was performed using Polifact program

\section{RESULTS AND DISCUSSIONS}

Results regarding green mass production

On the variants sown on $12,5 \mathrm{~cm}$ distance between roads (Tab. 1) we registered a green mass production between 48,79 t/ha and 64,39 t/ha. The highest production was registered on $\mathrm{V}_{3}$ fertilized with $\mathrm{N}_{75} \mathrm{P}_{60} \mathrm{~K}_{80}$, with a difference of $15,60 \mathrm{t} / \mathrm{ha}$ from control variant, very significant from statistical point of view. In which concerns the variants sown on $25 \mathrm{~cm}$ distance between roads green mass production registered was between 53,93 t/ha and 61,20 t/ha (Tab. 1). The highest green mass production was registered on the variant $\mathrm{V}_{2}$ fertilized with $\mathrm{N}_{50} \mathrm{P}_{60} \mathrm{~K}_{80}$, with a difference of $7,27 \mathrm{t} / \mathrm{ha} \mathrm{t} / \mathrm{h}$ a from control variant, very significant from statistical point of view.

Comparing the evolution of the variants sown on $12,5 \mathrm{~cm}$ distance between roads with those sown on $25 \mathrm{~cm}$ distance between roads (Tab. 2) we observed that these have a different reaction to mineral fertilization. The highest green mass production of $64,39 \mathrm{t} / \mathrm{ha}$ was registered on $\mathrm{V}_{3}$ -

Tab.1. The influence of experimental factors on green mass production

\begin{tabular}{cccccc}
\hline Nr.crt & Variant & $\begin{array}{c}\text { Production [t/ } \\
\text { ha] }\end{array}$ & $\begin{array}{c}\text { Percent } \\
{[\%]}\end{array}$ & Difference & Significance \\
\hline V1 D1 & 48,79 & 100,0 & 0,00 & Mt \\
\hline V2 D1 & 54,71 & 112,1 & 5,92 & $* * *$ \\
\hline V3 D1 & 64,39 & 132,0 & 15,60 & $* * *$ \\
\hline V4 D1 & 59,82 & 122,6 & 11,03 & $* * *$ \\
\hline V1 D2 & 53,93 & 100,0 & 0,00 & Mt. \\
\hline V2 D2 & 61,20 & 113,5 & 7,27 & $* * *$ \\
\hline V3 D2 & 60,77 & 112,7 & 6,84 & $* * *$ \\
\hline DL (p 5\%) 1,10 & V4 D2 & 57,35 & 106,3 & 3,42 & $* * *$ \\
\hline
\end{tabular}


Tab. 2. The influence which interaction between mineral fertilization- distance between roads has on green mass production

\begin{tabular}{|c|c|c|c|c|c|c|c|c|c|}
\hline \multirow{3}{*}{ Nr. Crt. } & \multirow{3}{*}{ Variant } & \multicolumn{8}{|c|}{ Classification } \\
\hline & & 1 & 2 & 3 & 4 & 5 & 6 & 7 & 8 \\
\hline & & 48,79 & 53,93 & 54,71 & 57,35 & 59,82 & 60,77 & 61,20 & 64,39 \\
\hline 1 & $\mathrm{~V}_{1} \mathrm{D}_{1}$ & & 5,14 & 5,92 & 8,56 & 11,03 & 11,98 & 12,41 & 15,60 \\
\hline 2 & $\mathrm{~V}_{1} \mathrm{D}_{2}$ & & & 3,28 & 3,42 & 5,89 & 6,84 & 7,27 & 10,47 \\
\hline 3 & $\mathrm{~V}_{2} \mathrm{D}_{1}$ & & & & 2,64 & 5,11 & 6,06 & 6,49 & 9,68 \\
\hline 4 & $\mathrm{~V}_{4} \mathrm{D}_{2}$ & & & & & 2,48 & 3,42 & 3,85 & 7,05 \\
\hline 5 & $\mathrm{~V}_{4} \mathrm{D}_{1}$ & & & & & & 0,95 & 1,38 & 4,57 \\
\hline 6 & $\mathrm{~V}_{3} \mathrm{D}_{2}$ & & & & & & & 0,43 & 3,63 \\
\hline 7 & $\mathrm{~V}_{2} \mathrm{D}_{2}$ & & & & & & & & 3,19 \\
\hline 8 & $\mathrm{~V}_{3} \mathrm{D}_{1}$ & & & & & & & & \\
\hline
\end{tabular}

Tab. 3. The influence of experimental factors on dry matter production

\begin{tabular}{|c|c|c|c|c|c|}
\hline Nr.crt.. & Variant & Production [t/ha] & $\begin{array}{c}\text { Percent } \\
{[\%]} \\
\end{array}$ & Difference & Significance \\
\hline 9 & V1 D1 & 11.84 & 100.0 & 0.00 & Mt \\
\hline 10 & V1 D2 & 13.38 & 113.0 & 1.54 & $* * *$ \\
\hline 11 & V4 D2 & 15.73 & 132.9 & 3.89 & $* * *$ \\
\hline 12 & V2 D1 & 14.34 & 121.1 & 2.50 & $* * *$ \\
\hline 13 & V4 D1 & 12.89 & 100.0 & 0.00 & Mt. \\
\hline 14 & V3 D2 & 14.77 & 114.6 & 1.88 & $* * *$ \\
\hline 15 & V2 D2 & 14.58 & 113.1 & 1.69 & $* * *$ \\
\hline 16 & V3 D1 & 13.30 & 103.2 & 0.41 & $*$ \\
\hline DL (p 5\%) & 0.28 & $\overline{\mathrm{DL}}$ & 6) 0.42 & & p 0.1\%) 0.67 \\
\hline
\end{tabular}

sown on $12,5 \mathrm{~cm}$, variant fertilized with $\mathrm{N}_{75} \mathrm{P}_{60} \mathrm{~K}_{80}$ This is followed by $\mathrm{V}_{2}$ sown on $25 \mathrm{~cm}$ which registered 61,19 t/ha.

The lowest green mass production of 48,79 $\mathrm{t} / \mathrm{ha}$ was registered on $\mathrm{V}_{1}$, control variant, unfertilized, sown on $12,5 \mathrm{~cm}$, with a difference of $15,60 \mathrm{t} /$ ha from the highest production.

\section{Results regarding dry matter production}

On the variants sown on $12,5 \mathrm{~cm}$ distance between roads we registered a dry matter production between $11,84 \mathrm{t} / \mathrm{ha}$ and $15,73 \mathrm{t} / \mathrm{ha}$ (Tab. 3). The highest production was registered on $\mathrm{V}_{3}$, fertilized with $\mathrm{N}_{75} \mathrm{P}_{60} \mathrm{~K}_{80}$, with a difference of 3,89 t/ha from control variant, very significant from statistical point of view. In which concerns the variants sown on $25 \mathrm{~cm}$ distance between roads dry matter production registered was bet- ween 12,89 t/ha and 14,77 t/ha (Tab. 3). The highest dry matter production was registered on $\mathrm{V}_{3}$ fertilized with $\mathrm{N}_{75} \mathrm{P}_{60} \mathrm{~K}_{80}$, with a difference of $1,88 \mathrm{t} /$ ha from control variant, very significant from statistical point of view.

Similar results were reported by Plesa et al., 2012 and Vintu et al., 2010.

Dry matter production follows green matter production (Tab. 3). Therefore the highest dry matter production of $15,73 \mathrm{t} /$ ha was registered on $V_{3}$, sown on $12,5 \mathrm{~cm}$, variant fertilized with $\mathrm{N}_{75} \mathrm{P}_{60} \mathrm{~K}_{80}$. This was followed by $\mathrm{V}_{2}$ sown on $25 \mathrm{~cm}$ which registered $14,77 \mathrm{t} /$ ha dry matter production (with a difference of $0,96 \mathrm{t} /$ ha compared to the highest production registered).

The lowest production was observed on $\mathrm{V}_{1}$, control variant, unfertilized, sown on $12,5 \mathrm{~cm}$ which registered 1,84 t/ha. 


\begin{tabular}{c|c|c|c|c|c|c|c|c|c}
\hline \multirow{2}{*}{ Nor. crt } & \multicolumn{7}{|c|}{ Classification } \\
\cline { 3 - 11 } & \multirow{2}{*}{ Variant } & 1 & 2 & 3 & 4 & 5 & 6 & 7 & 8 \\
\hline & & 11,84 & 12,89 & 13,30 & 13,38 & 14,34 & 14,58 & 14,77 & 15,73 \\
\hline & $\mathrm{V}_{1} \mathrm{D}_{1}$ & & 1,05 & 1,46 & 1,54 & 2,50 & 2,74 & 2,93 & 3,89 \\
\hline 2 & $\mathrm{~V}_{1} \mathrm{D}_{2}$ & & & 0,41 & 0,49 & 1,45 & 1,69 & 1,88 & 2,84 \\
\hline 3 & $\mathrm{~V}_{4} \mathrm{D}_{2}$ & & & & 0,08 & 1,04 & 1,28 & 1,47 & 2,43 \\
\hline 4 & $\mathrm{~V}_{2} \mathrm{D}_{1}$ & & & & & 0,97 & 1,21 & 1,40 & 2,36 \\
\hline 5 & $\mathrm{~V}_{4} \mathrm{D}_{1}$ & & & & & & 0,24 & 0,43 & 1,39 \\
\hline 6 & $\mathrm{~V}_{3} \mathrm{D}_{2}$ & & & & & & & 0,19 & 1,15 \\
\hline 7 & $\mathrm{~V}_{2} \mathrm{D}_{2}$ & & & & & & & & 0,96 \\
\hline 8 & $\mathrm{~V}_{3} \mathrm{D}_{1}$ & & & & & & & & \\
\hline
\end{tabular}

Tab. 4. The influence which interaction between mineral fertilization- distance between roads has on dry matter production

\begin{tabular}{|c|c|c|c|c|c|c|c|}
\hline \multicolumn{7}{|c|}{ Average error SX $=0,08()$} \\
\hline Distance in classification & 2 & 3 & 4 & 5 & 6 & 7 & 8 \\
\hline Values q & 3,46 & 3,59 & 3,65 & 3,68 & 3,69 & 3,70 & 3,70 \\
\hline Values DS theoretically & 0,28 & 0,29 & 0,29 & 0,29 & 0,29 & 0,29 & 0,29 \\
\hline
\end{tabular}

The evolution of floristic composition

Analysing the complex forage mixture formed by red clover (Trifolium pratense (15\%)), perennial ryegrass (Lolium perenne $(20 \%))$, festulolium (Festulolium (25\%)), tall fescue (Festuca arundinacea (25\%)) and timothy (Phleum pratense (10\%)) we observed the superiority of leguminous plant, namely red clover (Fig. 1). Red clover showed a high capacity for competition. Even if on sowing red clover occupied just 15\% from the total forage mixture, lesser than Festulolium (25\%), under the influence of experimental factors he registered the highest percent of participation in mixture. The presence of red clover in this mixture was very stable, the only exception being $V_{3}$, sown on 25 $\mathrm{cm}$ where red clover's place was exchanged with Festulolium. Red clover is followed by Festulolium and perennial ryegrass. Reds' clover high capacity for competition was highlighted also by Søegaard and Weisbjer, 2007. Analysing the behaviour of several species into an experience with forage mixtures they have noted that Festulolium had a strong reaction on fertilization and showed higher capacity for competition than perennial ryegrass.

Tall fescue has almost the same percent of participation in forage mixture like timothy. Accor- ding to bibliography timothy has a good behaviour when is cultivated together with cocksfoot or tall fescue (AWI et al., 2012). The registered data confirm previous researches which state that timothy isn't compatible with more aggressive species like Lolium perenne or Bromus sp. (AWI et al., 2012).

\section{CONCLUSIONS}

Analysing the evolution of experimental variants we observed that they have different reaction to technological factors. In which concerns distance between rows we have noticed that the studied mixture is suitable to be sown on $25 \mathrm{~cm}$ between rows. On this density we registered the highest green mass production (53,93 t/ha) and dry matter production $(12,89 \mathrm{t} / \mathrm{ha}$; compared to control variant, unfertilised). In which concerns the evolution of floristic composition, ratios between species stained stable. Distance between rows influenced Lolium perene and Festulolium, whose proportion in mixture are reversed on $25 \mathrm{~cm}$ density.

Species show strong reaction to fertilization. The lowest production, both of green mass and dry matter production are registered on control variant, unfertilized. Fertilization results in production 


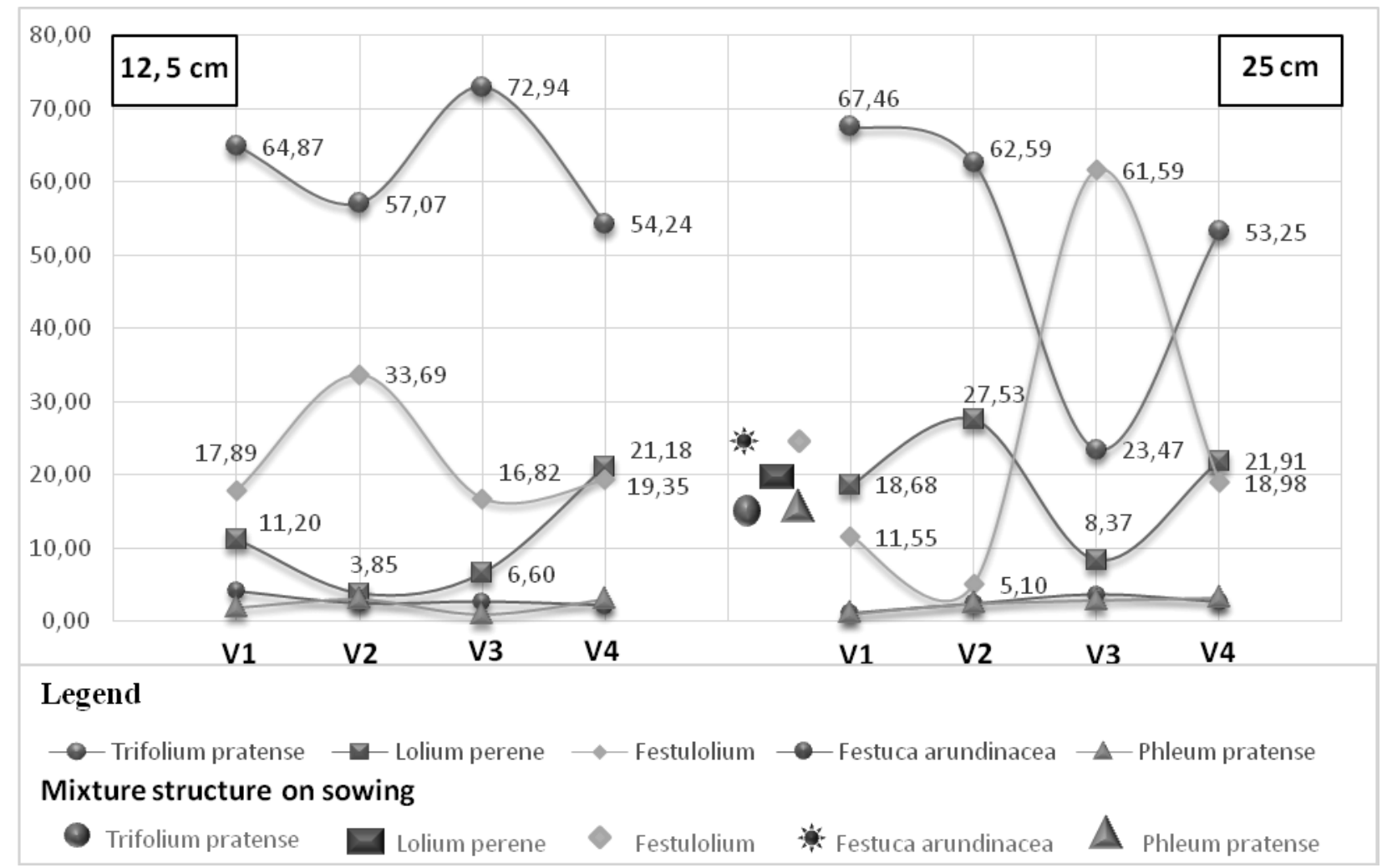

Fig. 1. Evolution of floristic composition

increases (with significant difference compared to control variant). For the studied mixture we recommend fertilization with $\mathrm{N}_{75} \mathrm{P}_{60} \mathrm{~K}_{80}$.

The results helped us to recommend the most suitable culture technology for the forage mixture studied (in the soil-climatic condition similar to those from the experimental area.) Therefore we recommend that the studied mixtures should be sown on $12,5 \mathrm{~cm}$ distance between rows and should be fertilized with $\mathrm{N}_{75} \mathrm{P}_{60} \mathrm{~K}_{80}$ (variant which registered the highest green mass $(64,39 \mathrm{t} / \mathrm{ha})$ and dry matter production $(15,75 \mathrm{t} / \mathrm{ha})$.

\section{REFERENCES}

1. AWI ; GRDC ; MLA ; RIRDC Dairy Australia (2012). Pastures Australia. A collaboration between AWI, GRDC, MLA, RIRDC and Dairy Australia

2. Liebman M. (1995). Polyculture cropping systems. In: M. Altieri (ed.). Agroecology: the Science of Sustainable Agri- culture. 2nd ed. Westview Press, Boulder, CO. p. 205-218.

3. Maruşca T., Mocanu V.,. Cardaşol V, Hermenean I., Blaj V. A., Oprea G., Tod M. A. (2010). Ghid de producere ecologică a furajelor de pajişti montane. Editura Universităţii Transilvania din Braşov. p 7.
4. Picasso V. D., Brummer E. C., Liebman M., Dixon P. M. and Wilsey B. J. (2011). Diverse perennial crop mixtures sustain higher productivity over time based on ecological complementarity, Renewable Agriculture and Food Systems: 26(4); 317-327.

5. Plesa D. B., Mihai Gh., Sima N., Sima R., Medrea I., Criste D. (2012). The Study of Perennial Grasses and Legumes Mixtures in the Environmental Conditions Part 1: The Evolution of Mixtures Productivity from Someselor Plateau, Scientific Papers: Animal Science and Biotechnologies, 45(1). Pp 404-409

6. Rotar I. (2010). Grassland culture (Risoprint printhouse), Cluj-Napoca.

7. Søegaard K., Weisbjerg M. R. (2012). Herbage quality and competitiveness of grassland legumes in mixed swards, Permanent and temporary grassland: plant, environment and economy. Proceedings of the 14th Symposium of the European Grassland Federation, Ghent, Belgium, 3-5 September 20072007 pp. 166-169

8. Staniak M. (2011). Feed value of mixtures of Festulolium braunii (K. Richt.) a. camus with Trifolium pratense L. depending on nitrogen fertilization, Acta Sci. Pol., Agricultura 10(1), 65-77

9. Vântu V., Irina Talpan, Ionel A., Samuil C. (2010). Influence of mixture and fertilizationon the behaviour of some grassesand perennial legume species on temporary pastures in the Moldavian forest steppe; Romanian Journal of Grsslands and Forage Crops, , 1 Cluj-Napoca. 